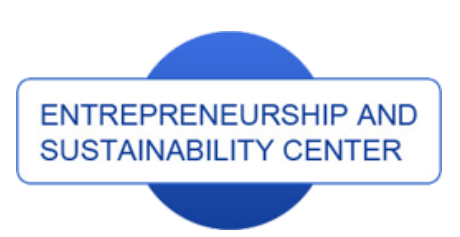

Publisher

http://jssidoi.org/esc/home

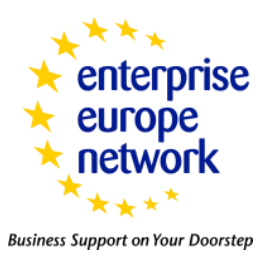

CASPA

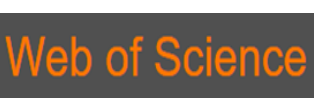

1) Clarivate

\title{
INSTITUTIONAL DETERMINANTS OF ENVIRONMENTAL POLLUTION IN RUSSIA: A NON- LINEAR ARDL APPROACH
}

\author{
Dmitry Burakov ${ }^{1}$, Alexander Bass ${ }^{2}$ \\ $1^{*}$ Moscow State Institute of International Relations (MGIMO-University), Department of Banks, Monetary Circultation and \\ credit, Prospect Vernadskogo, 76, 119454, Moscow, Russia \\ ,2 Financial University under the Government of the Russian Federation, Department of financial markets and banks, \\ Leningradskiy Prospect, 49, 125993, Moscow, Russia
}

E-mail: ${ }^{1 *}$ dbur89@yandex.ru (corresponding author)

Received 24 February 2019; accepted 10 July 2019; published 30 September 2019

\begin{abstract}
This paper aims to examine how institutional factors affect carbon dioxide emission in case of Russia with an emphasis on the asymmetrical effects of corruption. Institutional factors include corruption perception in the sampled economy and income inequality. The study deploys a non-linear autoregressive distributed-lagged approach to the hypothesis testing. Using the data for the period 1996-2018 of the sampled factors, affecting carbon dioxide emission in Russia, we aim to find the existence of the cointegration between the variables and determine the existence of the asymmetrical effects. In the results of the empirical investigation it was found that carbon dioxide emissions, corruption and income inequality in Russia are cointegrated. In both the long and short run, positive shocks in corruption increase environmental degradation in Russia. A $1 \%$ increase in corruption leads to a $0.13 \%$ and $0.17 \%$ rise in $\mathrm{CO} 2$ emission in the short and long run respectively under 5\% significance level. Income inequality is found to be a statistically insignificant determinant of carbon dioxide emission in Russia.
\end{abstract}

Keywords: carbon dioxide emissions, corruption, income inequality, cointegration, asymmetrical effect

Reference to this paper should be made as follows: Burakov, D., Bass, A. 2019. Institutional determinants of environmental pollution in Russia: a non-linear ARDL approach, Entrepreneurship and Sustainability Issues 7(1): 510-524. http://doi.org/10.9770/jesi.2019.7.1(36)

JEL Classifications: D31, D73, Q43, Q56

\section{Introduction}

Environmental pollution is one of the main areas of research in the field of the environmental economics. The problems of climate changes, global warming and worsening quality of environment, brought to life by an increased industrial output, are related to an increased greenhouse gases emission, which include carbon dioxide, 


\section{ENTREPRENEURSHIP AND SUSTAINABILITY ISSUES}

ISSN 2345-0282 (online) http://jssidoi.org/jesi/ 2019 Volume 7 Number 1 (September) http://doi.org/10.9770/jesi.2019.7.1(36)

methane and nitrous oxide as well. Thus, environmental degradation sufficiently reduces the potential of sustainable development.

Concerning the studied country, one should notice, that Russia takes the $4^{\text {th }}$ place among other countries, contributing in the world carbon dioxide emissions, after China, the United States of America and India in total kilotons (kt). Yet, in terms of kilogram $(\mathrm{kg})$ of carbon dioxide emission per GDP, measured in 2010 US dollars, in 2014, according to the World Bank data (2018), Russia with $0.999 \mathrm{~kg}$ outplaced the US with $0.324 \mathrm{~kg}$. According to the world tendency among developed countries, carbon dioxide steadily declines. However, in Russia carbon dioxide emissions continue to rise. Since 1998 minimum, the level of carbon dioxide emissions has increased on 14\% up to 2014. If the GDP is taken into account, the picture changes: carbon dioxide emissions, measured as kg per 2010 US dollars of GDP, decline from 1.839 in 1998 to 0.999 in 2014 . This tendency is the result of using more friendly-environmental technologies in some sectors of the national economy.

Even taking into account the active use of technologies that contribute to the preservation of the environment, the question of pollution still stands rather sharp in Russia. One of the most striking answers to the question of environmental pollution is the formation and development of models of sustainable green growth, based on renewable energy sources. In other words, global green growth and sustainable development of the national economy are closely linked. Measuring the growth of the national income is, in most cases, framed by the gross domestic product concept. However, employing the GDP concept is thought to be narrow and incomplete, that is, it does not take into account the impact of the economy on the environment. In this regard, employing GDP for estimating national development is seen as insufficient to assess the sustainability and quality of such development. The industrial model of economic development implies extensive or intensive expansion of production and sales of goods and services on the basis of existing technologies. In most cases, non-renewable energy sources are the basis for economic development. The last decade has shown the deterioration of the environment and has led to the need to strengthen the role of renewable energy in the production of GDP. Thus, energy consumption is an important part of economic growth. On the one hand, energy consumption growth is associated with GDP growth. On the other hand, growth in energy consumption, ceteris paribus, is associated with increased $\mathrm{CO} 2$ emissions. Active use of renewable energy could reduce $\mathrm{CO} 2$ emissions and improve the environment, while at the same time ensuring sustainable development and green growth.

The case of Russia seems very significant, since on the one hand Russia really takes the $4^{\text {th }}$ place in terms of CO2 emissions, and on the other hand continues to actively increase energy consumption. For example, for 1998, the level of energy consumption in the Russian economy was 3,981.502 kg. of oil equivalent per capita. This value is a local minimum, as throughout the subsequent time a steady increase in energy consumption in the national economy is observed with a maximum value of $5,167.012 \mathrm{~kg}$. of oil equivalent per capita in 2012 . It is logical to assume that the energy consumption growth is associated on the one hand with the growth of the GDP, and on the other hand with the ongoing processes of urbanization, internal labor migration, with growth of marginal propensity to consume and other important factors. It is important to note that Russia is a net exporter of conventional types of energy resources. In this regard, the structure of energy consumption is quite stable and has not changed significantly for almost 20 years. In other words, abundancy of energy resources eliminates incentives for the use of renewable energy, thereby mitigating the stimuli for improving the environmental quality and ensuring sustainable green growth.

Confirmation of this thesis can be found if we refer to data on the consumption of renewable energy sources in the total amount of energy consumed. Data of the World Bank on renewable energy consumption in Russia shows a downward trend. As of 1990, renewable energy consumption as a percentage share of the total final energy consumption, was only $3.75 \%$. Over the next 3 years, the share of renewable energy consumption increased up to $4 \%$. Since 1995, the share of renewable energy consumption has been declining steadily. As of 2000, the share of 


\section{ENTREPRENEURSHIP AND SUSTAINABILITY ISSUES}

ISSN 2345-0282 (online) http://jssidoi.org/jesi/

2019 Volume 7 Number 1 (September)

http://doi.org/10.9770/jesi.2019.7.1(36)

renewable energy consumption had fallen to 3.5 per cent again. At the time of Russia's entry into the Great Recession of 2007-2009, the share of renewable energy consumption fell to 3.3\% and remains at this level.

The use of renewable energy sources is one of the key elements to ensure green growth and sustainable development in the national economy. From this point of view, the state of the renewable energy market in Russia is deplorable. On the one hand, the national policy encourages the use of renewable energy to preserve the environment and the implementation of plans to reduce $\mathrm{CO} 2$ emissions within the framework of international agreements. On the other hand, the scale of investments in green energy, respectively, in green economic growth is insufficient given the surplus of non-renewable energy resources, including oil and gas.

In addition to environmental and technological factors, the institutional environment is another important factor. For example, the level of corruption and income inequality could significantly impact the structure of energy consumption on the one hand and the level of environmental degradation on the other. For example, a high level of monopolization or cartelization of energy infrastructure and housing and communal services could lead to an inflated level of energy prices for both households and business entities. In order to reduce costs, the use of renewable energy for both personal and production purposes can be a good example of green growth of the markets, usually driven by small and medium-sized businesses.

Thus, it is logical to assume that a high level of corruption in the national economy can serve as a barrier to sustainable development and green growth based on the use of renewable energy sources, thereby supporting an increase in $\mathrm{CO} 2$ emissions.

Another important institutional factor is income inequality. It's assumed that income inequality is closely linked to the level of corruption of the national economy. It is believed that an increase in the level of corruption leads to increasing gaps between incomes of the rich and the poor. It is also known that high levels of corruption are associated with high $\mathrm{CO} 2$ emissions. In other words, increasing income inequality can reduce the capacity of households to use renewable energy to mitigate the assumption of the budget constraint. Thus, we assume that the high level of income inequality of the population can contribute to the environmental degradation.

\section{Literature review}

The existing literature on the green growth and sustainable development is associated with the search for indicators that characterize the sustainable progressive development of the national economy, taking into account the environmental issues. In this regard, international research on this issue adheres to a number of directions.

The first one is focused on the relationship between $\mathrm{CO} 2$ emissions, energy consumption and economic growth. E.g., Acaravci and Ozturk (2010) investigated the causal relationship between carbon dioxide emissions, energy consumption, and economic growth by using autoregressive distributed lag (ARDL) bounds testing approach of cointegration for nineteen European countries. They found evidence of a long-run relationship between carbon emissions per capita, energy consumption per capita, real gross domestic product (GDP) per capita and the square of per capita real GDP. Acheampong (2018), applying panel vector autoregression along with a systemgeneralized method of moment, examined the dynamic causal relationship between economic growth, carbon emissions and energy consumption for 116 countries over the period 1990-2014. The study found that energy consumption uni-directionally causes economic growth and carbon emission. Also a bi-directional causality between carbon emissions and economic growth was detected. Sekrafi and Sghaier (2018) investigated whether energy consumption, corruption, environmental quality, and political instability affect economic growth in 13 Middle East and North African (MENA) countries over the period 1984-2012. The results in the ,growth-CO2 emissions" nexus showed that economic growth affected $\mathrm{CO} 2$ emissions and energy consumption, while $\mathrm{CO} 2$ emissions affected economic growth. Pao and Tsai (2010) investigated the nexus on the panel of BRIC countries. 


\section{ENTREPRENEURSHIP AND SUSTAINABILITY ISSUES}

ISSN 2345-0282 (online) http://jssidoi.org/jesi/ 2019 Volume 7 Number 1 (September) http://doi.org/10.9770/jesi.2019.7.1(36)

They found that energy consumption has a positive and statistically significant impact on emissions. Nejat et al. (2015) investigated energy consumption, $\mathrm{CO} 2$ emissions and energy policies in the residential sector in China, the US, India, Russia, Japan, Germany, South Korea, Canada, Iran, and the UK. In some countries energy consumption led to significant GHG emissions. Islam et al. (2017) investigated the impact of energy consumption, economic growth, population, poverty, and forest area on carbon dioxide emissions by using the econometrics approaches for Malaysia, Indonesia and Thailand. The results showed that energy consumption and economic growth had positive relationship with CO2 emission. Bass (2019) investigated the relationship between electricity consumption and economic growth in Russia. Results showed that the sampled variables are cointegrated and there exists a long-run relationship between them. Yang et al. (2017) estimated the economyrelated GHG emissions in Russia over the period of 1998-2013 in terms of energy consumption emissions, industrial process emissions, animal husbandry emissions, and fugitive emissions. The results supported the Environmental Kuznets Curve hypothesis with Russia reaching the threshold in ten years. Tan and Tan (2018) investigated the causal relationship between real income, energy consumption and carbon dioxide emission in Malaysian industrial sector during the period of 1980-2014, by applying the time-series econometric techniques. The results show that a long-run relationship exists between the variables and unidirectional causality relationship from energy consumption and $\mathrm{CO} 2$ emissions to real income in both short and long-run. Ozturk and Acaravci (2010) examined the long run and causal relationship issues between economic growth, carbon emissions, energy consumption and employment ratio in Turkey by using autoregressive distributed lag bounds testing approach of cointegration. They found a long-run relationship between the variables at 5\% significance level in Turkey. Results for the existence and direction of Granger causality show that neither carbon emissions per capita nor energy consumption per capita cause real GDP per capita. Similar results for the Turkish case were obtained by Bozkurt and Akan (2014). They investigated economic growth, CO2 emissions and energy consumption relationship in Turkey by using cointegration test. The results showed that energy consumption positively affects economic growth, while $\mathrm{CO} 2$ emissions negatively affect it. The results of the EKC hypothesis testing for Turkish case, presented by Shahbaz et al. (2013), showed that energy intensity and economic growth increase CO2 emissions. Albiman et al. (2015) investigated the nexus in the Tanzania by applying Toda and Yamamoto nonCausality test. They found that economic growth rate and energy consumption per capita, both being unidirectional, cause environmental pollution through carbon emission in Tanzania. Moreover, they found that a significant and positive economic growth due to shocks from electricity per capita (energy consumption) and carbon emission with time, which is similar to Bass (2019) for the Russian case. Shahbaz et al. (2015) tested the EKC hypothesis for Portugal by applying autoregressive distributed lag bounds testing approach from 1971 to 2008. They augmented the traditional income-emissions model with variables such as energy consumption, urbanization, and trade openness in time series framework. Empirical results confirmed the evidence of EKC hypothesis in both the short-run and long-run. Shahzadd et al. (2017) examined the cointegrating relationship between carbon emissions, energy consumption, trade openness and financial development in Pakistan using ARDL bounds test. The results shower an inverted U-shaped relationship between carbon emission and energy consumption with economy beind below the threshold, stating that energy consumption induced CO2 emissions. Al-mulali and Sab (2018) investigated the impact of energy consumption and CO2 emissions on the United Arab Emirates's economic and financial development. The results showed that energy consumption and $\mathrm{CO} 2$ emissions had a long-run relationship with the economic and financial development indicators in the UAE. Also a causality from energy consumption to $\mathrm{CO} 2$ emissions was detected.

Yet, some studies state that the „energy consumption-economic growth-CO2 emissions“ nexus depends on the degree of the carbonisation of the national economy, dependent on the structure of the economy. Chang (2015), analyzing energy efficiency and environmental Kuznets curves in G7 group and BRICS countries, found that the G7 group has greater room for improvement in its carbonization value than the BRICS group before 2005; however, the latter has greater room for improvement in carbonization value than the former after 2005. 


\section{ENTREPRENEURSHIP AND SUSTAINABILITY ISSUES}

ISSN 2345-0282 (online) http://jssidoi.org/jesi/ 2019 Volume 7 Number 1 (September) http://doi.org/10.9770/jesi.2019.7.1(36)

Another important area of research for our study deals with the „corruption-emissions“ nexus. E.g., Sekrafi and Sghaier (2018) found that corruption has an indirect effect on economic growth through energy consumption and environmental quality, an indirect effect on environmental quality through economic growth and an indirect effect on energy consumption through CO2 emissions and GDP. Cole (2007), employing data for 94 countries covering the period 1987-2000, estimated both direct and indirect impacts of corruption on air pollution emissions. For both sulfur dioxide and carbon dioxide, corruption is estimated to have a positive direct impact on per capita emissions. Indirect effects are found to be negative and larger in absolute value than direct effects for the majority of the sample income range. As a result, the total effect of corruption on emissions is negative for all but the highest income countries in the sample. Bass (2019) investigated the impact of institutional quality and world oil prices on performance of Russian manufacturing sector. The results of the study showed that oil prices, institutional quality and economic growth in Russia are cointegrated in the long-run. Yet short-run effects are statistically insignificant. Results of Granger causality test show unidirectional causality running from oil prices and institutional quality to economic growth. Farooq et al. (2013) found that corruption impedes economic growth, while financial development adds in economic growth, which is similar to the Russian case. (Bass, 2019) Fredriksson et al. (2004) investigated the effect of corruption on energy policy outcomes in case of 12 OECD countries. The results show that greater corruptibility of policy makers reduces energy policy stringency. Sekrafi and Sghaier (2018) evaluated the impact of corruption on the environmental quality in Tunisia. The results showed a positive and significant relationship between control of corruption and economic growth, a negative and significant relationship between control of corruption and environmental quality and a negative and significant relationship between control of corruption and energy consumption. Arminen and Menegaki (2019) examines the causal relationships between economic growth, energy consumption and carbon dioxide emissions in 67 highincome and upper-middle-income countries. They found a bidirectional causal relationship between GDP and energy consumption. Also climate and weather variations are found to be more important determinants of energy consumption and $\mathrm{CO} 2$ emissions than corruption, which suggest that changes in institutional quality are likely to have only a limited impact on energy and environmental policies. Chen et al. (2018) examined an impact of environmental regulation, shadow economy and corruption on the environment in China. The results showed that levels of environmental regulation and shadow economy are positively related with pollution, although environmental regulation is effective only when shadow economy and corruption are controlled. Lopez and Mitra (2000) examined the implications of corruption and rent-seeking behavior by the government for the relationship between pollution and growth. The results indicated that corruption is not likely to preclude the existence of an inverted-U-shaped-Kuznets environmental curve. Jabeur and Sghaier (2018) investigated the relationship between corruption, energy consumption, economic growth and $\mathrm{CO} 2$ emissions in the MENA region. Results showed that economic growth caused $\mathrm{CO} 2$ emissions, energy consumption is positively and significantly related to economic growth and also may increase $\mathrm{CO} 2$ emissions. However, corruption moderates economic growth and worsens the environmental quality in the MENA region. Zhang et al. (2016) investigated the relationship between corruption and $\mathrm{CO} 2$ emissions for APEC countries. The results show that the effect of corruption on $\mathrm{CO} 2$ emissions is heterogeneous among APEC countries. There exist a significant negative effect in lower emission countries and an insignificant in higher emission countries. They also found that corruption may have not only a negative direct effect on $\mathrm{CO} 2$ emissions, but also a positive indirect effect through its effect on per capita GDP. Wang et al. (2018) investigated the interaction between, economic growth and $\mathrm{CO} 2$ emissions.The results showed that the moderating role of corruption is crucial in the relationship between economic growth and carbon dioxide emissions. They found that control of corruption reduce $\mathrm{CO} 2$ emissions. Furthermore, a significant moderating effect of corruption was observed by Wang et al. (2018) on the relationship between urbanisation and carbon dioxide emissions in the case of BRICS countries, which signifies poor environmental performance therein.

The third area of research deals with "inequality-energy consumption-emissions" nexus. E.g., Khan and Heinecker (2018) investigate the impact of incomes distribution on the energy efficiency. They show that rising disparity for distributions of population density in census blocks in metropolitan statistical areas affects energy consumption efficiency in a diametrically different manner in cities and nation states leading to a higher urban 


\section{ENTREPRENEURSHIP AND SUSTAINABILITY ISSUES}

ISSN 2345-0282 (online) http://jssidoi.org/jesi/ 2019 Volume 7 Number 1 (September) http://doi.org/10.9770/jesi.2019.7.1(36)

carbon footprint while increasing energy efficiency nationally. Dong and Hao (2018) estimated the impact of urban-rural income inequality on electricity consumption in China. The results showed that urban-rural income inequality was negatively related with electricity consumption. Hao et al. (2016) investigated the impacts of income inequality on carbon emissions per capita in China. The results indicated that carbon emissions per capita increase as the income gap expands for nationwide and in the eastern and non-eastern regions of China. Baek and Gweisah (2013) examined the growth-inequality-environment nexus in the U.S. They found that income equality had a beneficial effect on the environment, economic growth was found to enhance environmental quality, although energy consumption had a detrimental effect on the environment. The opposite results are obtained by Kasuga and Takaya (2017) for Japan. The authors found that inequality negatively affects air quality in the 1990s. Evidence for a causal effect of inequality on pollution was also provided in the study. The heterogeneity of the above describe results is supported by Grunewald et al. (2017). They investigated the link between income inequality and per capita carbon dioxide emissions. The results showed that the relationship between income inequality and per capita emissions depends on the level of income: for low and middle-income economies, higher income inequality is associated with lower carbon emissions while in upper middle-income and high-income economies, higher income inequality increases per capita emissions.

Given the literature review above, we aim to fill the gap on the determinants of sustainable development and green growth. The paper states that maintaining environmental quality is one of the necessary elements of achieving green growth. Thereby investigating factors, affecting the level of carbon dioxide emission (CO2) seems rather actual and important in order to achieve environmentally sustainable economic development. Unfortunately, most studies investigate various factors, affecting $\mathrm{CO} 2$ emissions, meanwhile the possible asymmetrical effects of corruption on environmental degradation as well as the impact of income inequality on $\mathrm{CO} 2$ emissions fall out of sight. That is why we aim to fill this gap on the example of Russian case.

\section{Materials and methods}

Given the heterogeneity of the obtained results, discussed in the previous section, we aim to fill the gap by enquiring into the nature of the relationship between $\mathrm{CO} 2$ emissions, corruption and income inequality for the Russian case. Then the basic equation can be presented as follows:

$$
\mathrm{CO}_{t}=\beta_{0}+\beta_{1} \mathrm{GINI}_{\mathrm{t}}+\beta_{2} \mathrm{CPI}_{t}+\varepsilon_{t}
$$

where $\mathrm{CO} 2$ represents emission per capita in the sampled country; $G I N I_{t}$ is income inequality measured by Gini coefficient for the sampled country; $C P I_{t}$ is the corruption level, measured by Corruption perception index.

Then we transform linear specification of the model into log-linear specification. The log-linear specification provides more appropriate and efficient results compared to simple linear functional form of the model (Cameron, 1994). Moreover, logarithmic form of variables gives direct elasticities for interpretations. Therefore, we specify the estimated equation in log-linear form:

$$
L C O 2_{t}=\beta_{1}+\beta_{G I N I_{t}} L G I N I_{t}+\beta_{C P I_{t}} L C P I_{t}+\mu_{t}
$$

Also we aim to test the possible asymmetrical effects in renewable energy consumption reaction to positive and negative shocks in total energy consumption in Russia in order to estimate the potential reaction of $\mathrm{CO} 2$ emissions to various stimuli. For this purpose, we are using the methodology, developed by Shin et al. (2014) and decompose the energy use variable: 


$$
\begin{aligned}
& L C P I_{t}^{+}=\sum_{t=1}^{t} \Delta L C P I_{t}^{+}=\sum_{t=1}^{t} \max \left(\Delta L C P I_{t}, 0\right) \\
& L C P I_{t}^{-}=\sum_{t=1}^{t} \Delta L C P I_{t}^{-}=\sum_{t=1}^{t} \min \left(\Delta L C P I_{t}, 0\right)
\end{aligned}
$$

Equations 3 and 4 divide the variable $\mathrm{CPI}_{t}$ into $\mathrm{CPI}_{t}^{+}$and $\mathrm{CPI}_{t}^{-}$by taking the positive and negative partial sums of the changes in $L C P I_{t}$.

In order to estimate Equation 2 after incorporating the asymmetrical effects of $C P I_{t}$, we are employing the nonlinear ARDL methodology, proposed by Shin et al. (2014). We employ exactly this model due to its advantages in presence of a mix order of integration as this technique follows the lower and upper bound F-values. In which, lower bound values are provided by assuming level stationary variables i.e. I(0) and upper bound values are provided by assuming the first differenced stationary variables i.e. I(1). Yet, if the variables are I(2) integrated, the use of this methodology is unacceptable. Also of great importance is that the NARDL approach allows differences in lags of the sampled variables in the data generating process. Endogenuity problem is absent in the NARDL approach because it also corrects for residual serial correlation. Also the NARDL approach allows to estimate short-run parameters by the means of the error correction model (ECM) adjustments.

That is why the first step of this study is to check the stationarity of the sampled variables and determine whether it is achieved without second differencing procedure. For this we employ four alternative unit root tests: the Augmented Dickey-Fuller (ADF) test (Dickey and Fuller, 1979), the Dickey-Fuller generalized least squares (DF-GLS) test proposed by Elliot et al. (1996), the Phillips and Perron (1988) PP test and the KPSS (Kwiatkowski et al., 1992) test. The null hypothesis of the ADF, DF-GLS and PP tests states that the there exists a unit root, while the alternative hypothesis states that the series are generated by a stationary process. The null hypothesis of the KPSS test is of reverse nature - it states that the series are stationary, while the alternative hypothesis states that the unit root is present.

The first step in the NARDL procedure is the determining the co-integration existence between the sampled variables. The bounds test examines long-run relationships, where the NARDL framework of the model (Equation 2) is expressed in Equation 5:

$$
\begin{aligned}
& \Delta L C O 2_{t}=\gamma_{1}+\sum_{i=1}^{p} \gamma_{i} \Delta L C O 2_{2 t-i}+\sum_{j=0}^{q} \gamma_{j} \Delta L C P I_{t-j}^{+}+\sum_{t=0}^{r} \gamma_{t} \Delta L C P I_{t-j}^{-}+\sum_{s=0}^{n} \gamma_{l} \Delta L G I N I_{t-s}+ \\
& +\gamma_{L C O 2_{t-1}} L C O 2_{t-1}+\gamma_{L C P I_{t-1}} L C P I_{t-1}^{+}+\gamma_{L C P I_{t-1}} L C P I_{t-1}^{-}++\gamma_{G I N I_{t-1}}=L G I N I_{t-1}+\mu_{t}
\end{aligned}
$$

where, $\gamma_{L C O 2_{t-1}}, \gamma_{L G I N I_{t-1}}, \gamma_{L C P I_{t-1}}$ represent short-term coefficients of the sampled variables in the logarithmic forms and $\gamma_{i}, \gamma_{j}, \gamma_{t}, \gamma_{l}$, represent the long-term coefficients of the sampled variables in the logarithmic forms; $q, r, m, n$ are optimal lag lengths selected by Akaike Information Criterion (AIC) after imposition of maximum of 2 lags for each variable. We avoid more than 2 lags to save the degree of freedom. Moreover, Perron (1989) suggested to include maximum 4 lags for high frequency data like quarterly data and maximum 2 lags for low frequency data like annual data in our case.

After detecting the optimal lag length, Equation 5 may be tested for cointegration. Presence or absence of the relationship is tested by employing the joint $\mathrm{F}$ or statistics of the Wald test. The null hypothesis of no cointegration in the model is $\gamma_{L C O 2_{t-1}}=\gamma_{L C P I+}{ }_{t-1}=\gamma_{L C P I-t-1}=\gamma_{L G I N I_{t-1}}=0$. The alternative hypothesis of cointegration between the variables is $\gamma_{L C O 2_{t-1}} \neq \gamma_{L C P I+} \neq \gamma_{L C P I-1-1} \neq \gamma_{L G I N I_{t-1}} \neq 0$. 


\section{ENTREPRENEURSHIP AND SUSTAINABILITY ISSUES}

ISSN 2345-0282 (online) http://jssidoi.org/jesi/ 2019 Volume 7 Number 1 (September) http://doi.org/10.9770/jesi.2019.7.1(36)

To test the significance of the obtained results, the critical values for the bound test, reported in Pesaran et al. (2001) are used. The critical bounds are set as if the variables are of $\mathrm{I}(0)$ and are of I(1). If the F-statistics is above the upper bound of the critical values, the null hypothesis is rejected. If the F-statistics is below the lower critical bound, the null hypothesis is accepted. If the F-statistics is between the bounds, the results of the test are inconclusive.

The goodness of fit for NARDL model is checked through stability tests such as cumulative sum of recursive residuals (CUSUM) and cumulative sum of squares of recursive residuals (CUSUMSQ).

The study aims to test the short and long-run relationships between $\mathrm{CO} 2$ emission, corruption and income inequality. The variables include carbon emission per capita in the sampled country, income inequality is measured by Gini coefficient for the sampled country and corruption level, measured by Corruption perception index by Transparency International. The data are collected from the World Bank's World Development Indicators database, Transparency International reports on Corruption Perception Index and Russian statistical database when and where needed.

\section{Results and discussion}

The study is based on Russian data for the sampled variables for the period 1996-2018 and is aimed test the short and long-run relationships between $\mathrm{CO} 2$ emission, corruption and income inequality as well as to investigate the possible asymmetrical effects of corruption on $\mathrm{CO} 2$ emissions. For the purposes of the study the bounds test approach is employed, that assumes the use of the variables with different order of integration, except integration of order above I(1). The first goal, then, should be the investigation of the order of sampled variables integration, achieving which supposes testing the variables for stationarity in order to determine if the ARDL approach suits the study. We employ four different unit root tests, including the ADF, the DF-GLS, the PP and the KPSS tests. The results of the tests for stationarity show that all the sampled variables of the study are generated by a stationary process. Given the results of the different unit root tests, we can assume that the variables in the study are integrated of the order 0 or 1 and none is integrated of the order above 1.

Given that the variables of the study are not integrated of the order 2 we can proceed with the cointegration test. The first step in the NARDL co-integration analysis requires identification of the optimal lag length under the unrestricted vector autoregression. For these purposes we use the Schwarz Criterion (SC), the Akaike Information Criterion (AIC) and the Hannan-Quinn Information criterion (HQ). All the information criteria stand for the lag length of 1 year (Table 1).

Table 1. Results of optimal lag length selection

\begin{tabular}{|c|c|c|c|c|c|c|}
\hline Lag & LogL & LR & FPE & AIC & SC & HQ \\
\hline 0 & 126.8624 & NA & $5.43 \mathrm{e}-11$ & -12.28624 & -12.08709 & -12.24736 \\
\hline 1 & 202.5397 & $113.5160 *$ & $1.45 \mathrm{e}-13 *$ & $-18.25397 *$ & $-17.25824 *$ & $-18.05959^{*}$ \\
\hline 2 & 213.3072 & 11.84423 & $3.09 \mathrm{e}-13$ & -17.73072 & -15.93840 & -17.38084 \\
\hline
\end{tabular}

Note: * indicates lag order selected by the criterion AIC - Akaike information criterion, SC - Schwarz information criterion, HQ: HannanQuinn information criterion. 
Then we can proceed to determining the long-run relationships between the variables of the study. To check the variables on the existence of the long-run relationship we employ the bound F-test for Equation 5. The results of the bounds test for the estimated equation are presented in Table 2.

Table 2. Cointegration F-test results

\begin{tabular}{|c|c|c|c|c|c|c|}
\hline F-statistics & $\mathbf{9 0 \%} \mathbf{L B}$ & $\mathbf{9 0 \%} \mathbf{U B}$ & $\mathbf{9 5 \%} \mathbf{L B}$ & $\mathbf{9 5 \%} \mathbf{U B}$ & $\mathbf{9 9 \%} \mathbf{L B}$ & $\mathbf{9 9 \%} \mathbf{U B}$ \\
\hline 4.42 & $2.72 *$ & $3.77 *$ & $3.23 *$ & $4.35 *$ & 4.29 & 5.61 \\
\hline
\end{tabular}

Note: Null hypothesis of the ARDL bounds test is: No long-run relationship exists. LB - low bound, UB - upper bound. If the F test statistic falls between lower and upper bounds the result is inconclusive. If it is below lower bound, the null hypothesis cannot be rejected. If the test statistics is above upper bound, the null hypothesis of no co-integration is rejected (*).

\section{Source: own calculations}

The results of the cointegration F-test show that the resulting F-statistics are above the upper bound and statistically significant at $10 \%$ and $5 \%$ significance level. The results show that the sampled variables are cointegrated and the long-run relationship between the variables exists in the Russian case.

Given that the sampled variables are cointegrated in the long-run, we can proceed to the next stage, that requires estimation of the long and short-run coefficients. Given that the NARDL model was estimated in the logarithmic form, we can estimate how a shock in $1 \%$ of the explanatory variables affect the dependent variable both in the long and short run.

The estimates for the short-run relationships are presented in Table 3.

Table 3. NARDL short-run results.

\begin{tabular}{|l|c|c|c|c|}
\hline \multicolumn{1}{|c|}{ Regressor } & Parameters & S.E. & t-statistics & p-value \\
\hline \multirow{2}{*}{$\Delta L C P I+$} & 0.133810 & 0.070107 & 1.908651 & $0.0733^{* * *}$ \\
\hline \multirow{2}{*}{$\Delta L C P I-$} & 0.000001 & 0.103028 & 0.000009 & 1.0000 \\
\hline \multirow{2}{*}{$\Delta L G I N I$} & 0.524538 & 0.504683 & 1.039342 & 0.3132 \\
\hline$E C M t-1$ & -0.752844 & 0.202592 & -3.716050 & $0.0017^{*}$ \\
\hline \multicolumn{4}{|c|}{ Diagnostic test statistics } \\
\hline$R^{2}$ & \multicolumn{3}{|c|}{0.8536} \\
\hline DW-statistic & \multicolumn{3}{|c|}{2.0235} \\
\hline F-statistic & \multicolumn{3}{|c|}{6.714} \\
\hline RSS & \multicolumn{4}{|c|}{0.01} \\
\hline
\end{tabular}

Note: $*$ and $* *$ denote the rejection of the null hypothesis at the $5 \%$ and $10 \%$ significance levels respectively. $\beta$ column reports estimated coefficients.

\section{Source: own calculations}

As can be seen from the results of the short-run relationship estimation, the error correction term is negative in sign and statistically significant at $1 \%$ level. This result confirms the presence of the co-integration. The value of 
the ECM coefficient is 0.752 , that allows to assume that in Russia $75 \%$ of the disequilibrium in the carbon dioxide emission is rectified in the short-run given the explanatory variables.

Given the results of the short-run estimates, we can conclude that the only determinant among the selected variables, that affect $\mathrm{CO} 2$ emissions is a positive shock in corruption. In other words, a $1 \%$ increase in corruption perception increases $\mathrm{CO} 2$ emissions on $0.13 \%$ under $10 \%$ significance level. Another interesting result is that a $1 \%$ decrease in corruption is not statistically significant at all. Yet, we can assume that only an increase in corruption stimulates environmental degradation in Russia, while a decrease in corruption does not affect the structure of the energy sector. The explanation of such result may lie in the lack of stimuli to support green growth through exploitating renewable energy consumption. Also the short run estimates show that income inequality doesn't play a statistically significant role in explaining $\mathrm{CO} 2$ emissions in Russia. However, the results may be alternative if one would decompose the GINI coefficient in positive and negative series.

The picture won't change if we look at the long run estimates of the nARDL model in Table 4.

Table 4. NARDL long-run results.

\begin{tabular}{|c|c|c|c|c|}
\hline Regressor & Parameters & S.E. & t-statistics & p-value \\
\hline$L C P I+$ & 0.177740 & 0.081592 & 2.178408 & $0.0437 *$ \\
\hline$L C P I-$ & 0.000001 & 0.136852 & 0.000009 & 1.0000 \\
\hline LGINI & 0.696743 & 0.667442 & 1.043899 & 0.3111 \\
\hline \multicolumn{5}{|c|}{ Diagnostic test statistics } \\
\hline Test type & \multicolumn{2}{|c|}{$t$-statistics } & \multicolumn{2}{|c|}{$p$-value } \\
\hline$\chi_{s c}^{2}$ & \multicolumn{2}{|c|}{1.118} & \multicolumn{2}{|c|}{0.520} \\
\hline$\chi_{E F}^{2}$ & \multicolumn{2}{|c|}{1.437} & \multicolumn{2}{|c|}{0.988} \\
\hline$\chi_{N}^{2}$ & \multicolumn{2}{|c|}{1.174} & \multicolumn{2}{|c|}{0.555} \\
\hline$x_{H}^{2}$ & \multicolumn{2}{|c|}{1.577} & \multicolumn{2}{|c|}{0.356} \\
\hline
\end{tabular}

Note: $*$ and $* *$ denote the rejection of the null hypothesis at the $5 \%$ and $10 \%$ significance levels respectively. $\beta$ column reports estimated coefficients. $\chi^{2}{ }_{S C}, \chi_{F F}^{2}, \chi_{N}^{2}, \chi_{H}^{2}$ present the Breusch-Godfrey serial correlation LM test, the Ramsey RESET test of functional form misspecification, the Jarque-Bera normality test and the Breusch-Pagan-Godfrey heteroscedasticity test, respectively.

Source: own calculations

As the short run estimates, the long run ones also show that a positive shock in corruption is an important determinants of environmental degradation in Russia. A $1 \%$ increase in corruption leads to an almost $0.17 \%$ rise in carbon dioxide emission, stressing the importance of institutional quality for sustainable economic growth. The other parameters seem to be of no importance, given their statistical insignificance. The decrease in corruption is found to be statistically insignificant for the purpose of environment preservation. This results show that the main problem of environmental degradation in Russia lies more in technological factors, such as the structure of energy resources, where almost $60 \%$ go for coal, gas and oil, rather than in institutional ones. 
The last step in the nARDL approach is estimating the stability of the model. For this purpose, we employ the cumulative (CUSUM) and the cumulative sum of squares (CUSUMSQ) stability tests, proposed by Brown et al. (1975). The results of the CUSUM and CUSUMSQ tests are presented in Figures 1 and 2.

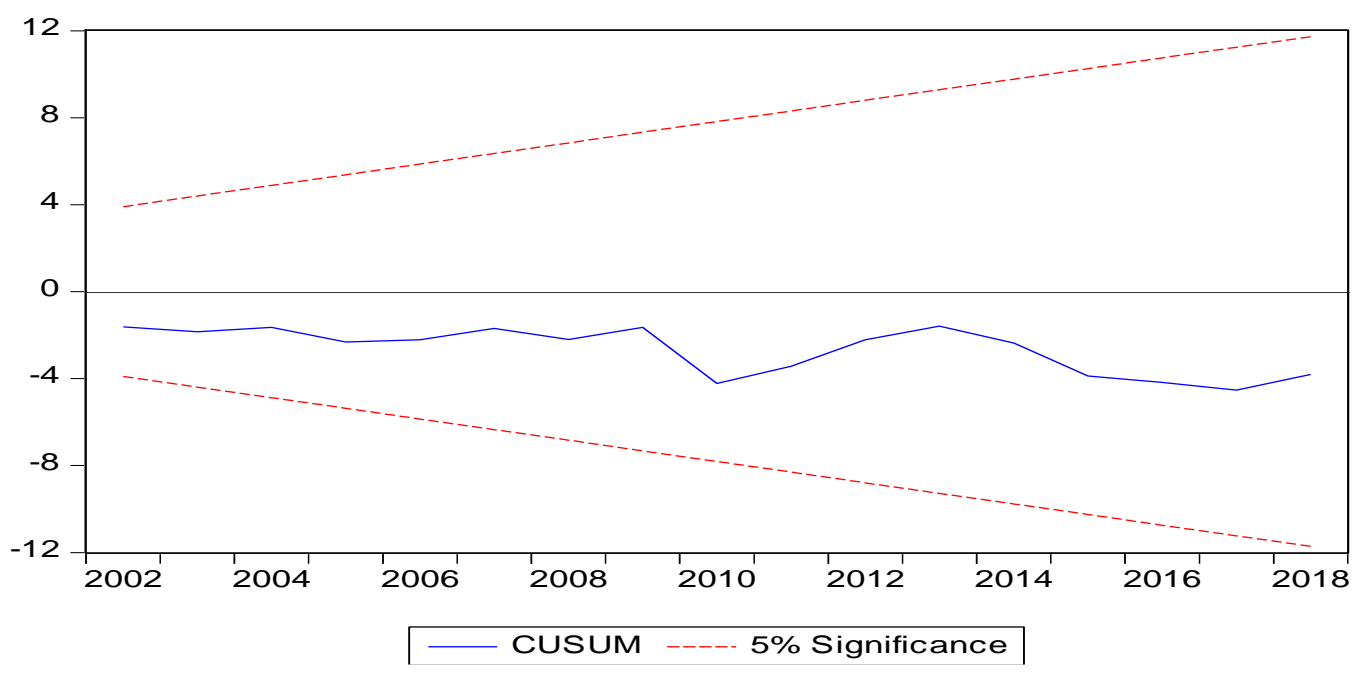

Fig.1. Results of CUSUM test

Source: own calculations

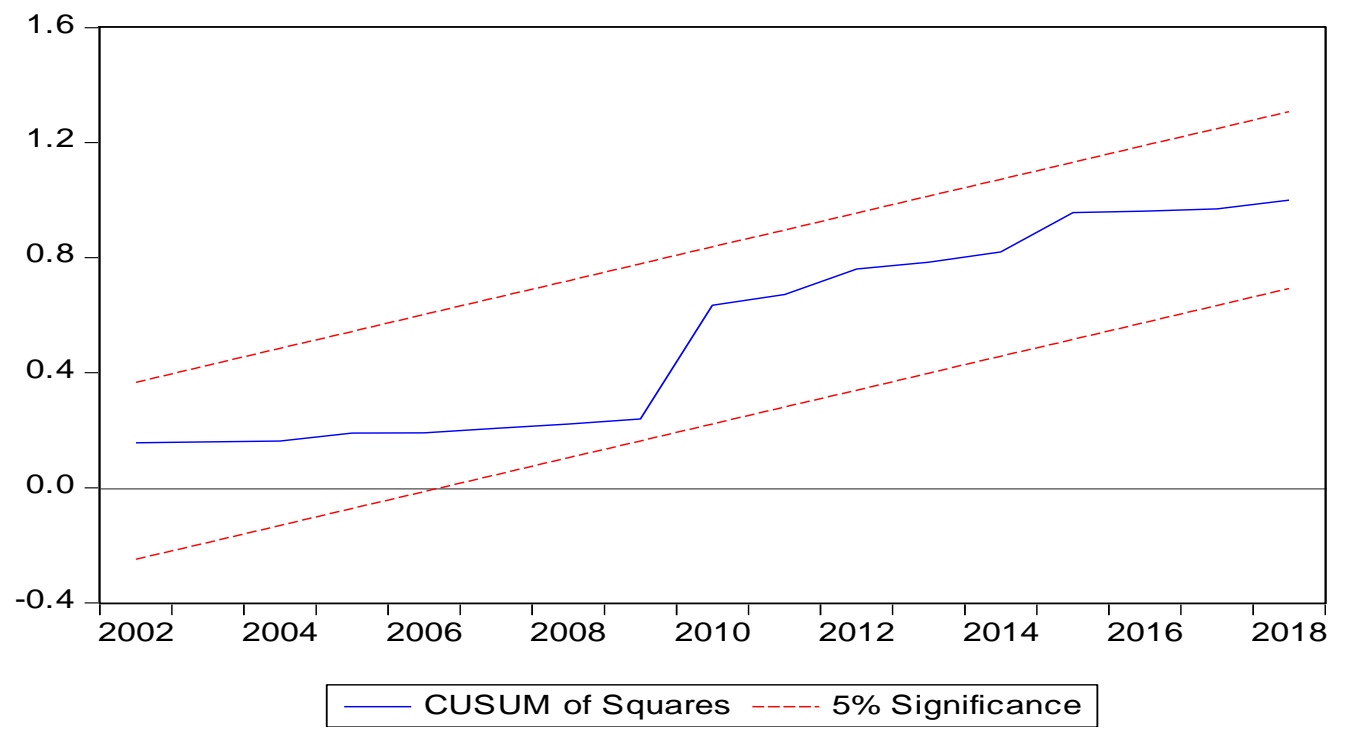

Fig.2. Results of CUSUMSQ test

Source: own calculations

As can be seen from Figures 1 and 2, the plots of the CUSUM and the CUSUMSQ statistics are located within the $5 \%$ significance critical bounds, which proves the stability of the developed model. 


\section{ENTREPRENEURSHIP AND SUSTAINABILITY ISSUES}

ISSN 2345-0282 (online) http://jssidoi.org/jesi/

2019 Volume 7 Number 1 (September)

http://doi.org/10.9770/jesi.2019.7.1(36)

\section{Conclusion}

This paper investigates the impact of income inequality and corruption on carbon dioxide emissions in Russia. Also the paper aims to explore the potential impact of positive and negative shocks in corruptio on carbon dioxide emissions in Russia for the period 1996-2018. The study employs non-linear autoregressive distributed lag approach.

The results show that all the variables are cointegrated in the long run. The results of the long run estimates show that a $1 \%$ increase in corruption leads to a $0.13 \%$ rise in $\mathrm{CO} 2$ emissions in Russia in the short-run, while a $1 \%$ increase in corruption in the long run leads to a $0.18 \%$ rise in carbon dioxide emissions under $5 \%$ significance level. The decrease in corruption is found to be statistically insignificant for the purpose of environment preservation. This results show that the main problem of environmental degradation in Russia lies more in technological factors, such as the structure of energy resources, where almost $60 \%$ go for coal, gas and oil, rather than in institutional ones. However, rising corruption negatively affects environmental quality because of high rate of return of non-renewable energy sector. The income inequality is found to be statistically insignificant. However, decomposition of the GINI coefficient for positive and negative shocks may give another results.

The results also reveal the presence of asymmetrical effects of corruption on carbon dioxide emissions and confirm its significance as important determinant of environmental pollution in Russia.

\section{References}

Acaravci, A., Ozturk, I. 2010. On the relationship between energy consumption, CO2 emissions and economic growth in Europe. Energy, 35(12): 5412-5420. https://doi.org/10.1016/j.energy.2010.07.009

Albiman, M.M., Suleiman, N. \&Hamad Omar Baka. 2015. The relationship between energy consumption, CO2 emissions and economic growth in Tanzania. International Journal of Energy Sector Management, 9(3): .361-375, https://doi.org/10.1108/IJESM-05-2014-0006

Acheampong, A. 2018. Economic growth, CO2 emissions and energy consumption: What causes what and where?", Energy Economics, 74: 677-692. https://doi.org/10.1016/i.eneco.2018.07.022

Al-mulali, U. and Che Normee Binti Che Sab, 2018. Energy consumption, CO2 emissions, and development in the UAE. Energy Sources, Part B: Economics, Planning, and Policy, 13(4): 231-236, https://doi.org/10.1080/15567249.2012.689796

Arminen, H. and Angeliki N. Menegaki, 2019. Corruption, climate and the energy-environment-growth nexus. Energy Economics, 80: 621634. https://doi.org/10.1016/j.eneco.2019.02.009

Baek, J. and Gweisah, G. 2013. Does income inequality harm the environment?: Empirical evidence from the United States. Energy Policy, 62: 1434-1437. https://doi.org/10.1016/j.enpol.2013.07.097

Bass, A. 2019. Does Electricity Supply Matter for Economic Growth in Russia: A Vector Error Correction Approach? International Journal of Energy Economics and Policy, 8(5): 313-318.

Bass, A. 2019. Do institutional quality and oil prices matter for economic growth in Russia: An empirical study. International Journal of Energy Economics and Policy, 9(1): 76-83. https://doi.org/10.32479/ijeep.7091

Bozkurt, C. and Y.Akan, 2014. Economic growth, CO2 emissions and energy consumption: the Turkish case. International Journal of Energy Economics and Policy, 4(3): 484-494.

Brown, R. L., Durbin, J., Evans, J. M. 1975. Techniques for testing the constancy of regression relations over time. Journal of the Royal Statistical Society. Series B. Methodological, 37: 149-163. 


\section{ENTREPRENEURSHIP AND SUSTAINABILITY ISSUES}

ISSN 2345-0282 (online) http://jssidoi.org/jesi/ 2019 Volume 7 Number 1 (September) http://doi.org/10.9770/jesi.2019.7.1(36)

Cameron, S. 1994. A review of the econometric evidence on the effects of capital punishment. Journal of Socio-Economics, $23: 197-214$.

Chang, M.-C. 2015. Room for improvement in low carbon economies of G7 and BRICS countries based on the analysis of energy efficiency and environmental Kuznets curves. Journal of Cleaner Production, 99: 140-151. https://doi.org/10.1016/j.jclepro.2015.03.002

Chen, H., Hao, Y. Li, J. and Xiaojie Song, 2018. The impact of environmental regulation, shadow economy, and corruption on environmental quality: Theory and empirical evidence from China, Journal of Cleaner Production, 195: 200-214. https://doi.org/10.1016/i.jclepro.2018.05.206

Cole, M.A. 2007. Corruption, income and the environment: an empirical analysis". Ecological Economics, 62(3-4): 637-647 https://doi.org/10.1016/j.jclepro.2015.03.002

Tan, C.-C. \& Tan, C. 2018. Energy consumption, CO2 emissions and economic growth: a causality analysis for Malaysian industrial sector. International Journal of Energy Economics and Policy, 8(4): 254-258.

Dickey, D. A., Fuller, W. A. 1979. Distribution of the estimators for autoregressive time series with a unit root. Journal of the American Statistical Association, 74(366a): 427-431. https://doi.org/10.1080/01621459.1979.10482531

Dong, X.-Y. \& Yu Hao, 2018. Would income inequality affect electricity consumption? Evidence from China. Energy, 142: $215-227$. https://doi.org/10.1016/j.energy.2017.10.027

Elliot, G., Rothenberg, T., Stock, J. 1996. Efficient tests for an autoregressive unit root. Econometrica, 17:143-178.

Farooq, A., Shahbaz, M., Arouri, M., Teulon, F., 2013. Does corruption impede economic growth in Pakistan?. Economic Modelling, 35, 622-633.64(4): 813-836. https://doi.org/10.2307/2171846

Fredriksson, P.G., Vollebergh, H. and Dijkgraaf, E. 2004. Corruption and energy efficiency in OECD countries: theory and evidence. Journal of Environmental Economics and Management, 47(2): 207-231. https://doi.org/10.1016/j.jeem.2003.08.001

Grunewald, N., Klasen, S., Martinez-Zarzoso, I. and Chris Muris, 2017. The Trade-off between Income Inequality and Carbon Dioxide Emissions. Ecological Economics, 142: 249-256. https://doi.org/10.1016/j.ecolecon.2017.06.034

Hao, Y. Chen, H. and Qianxue Zhang, 2016. Will income inequality affect environmental quality? Analysis based on China's provincial panel data. Ecological indicators, 67: 533-542. https://doi.org/10.1016/j.ecolind.2016.03.025

Islam, R., Ahmad Bashawir Abdul Ghani and Emil Mahyudin, 2017. Carbon dioxide emission, energy consumption, economic growth, population, poverty and forest area: evidence from panel data analysis. International Journal of Energy Economics and Policy, 7(4): 99106.

Jabeur, S. \& Sghaier, A. 2018. The relationship between energy, pollution, economic growth and corruption: A Partial Least Squares Structural Equation Modeling (PLS-SEM) approach. Economics Bulletin, AccessEcon, 38(4): 1927-1946

Kasuga, H. and Masaki Takaya, 2017. Does inequality affect environmental quality? Evidence from major Japanese cities. Journal of Cleaner Production, 142(4): 3689-3701. https://doi.org/10.1016/j.jclepro.2016.10.099

Khan, F. and Paul Heinecker, 2018. Inequality and energy: Revisiting the relationship between disparity of income distribution and energy use from a complex systems perspective“, Energy Research and Social Science, 42: 184-192. https://doi.org/10.1016/j.erss.2018.03.026

Kwiatkowski, D., Phillips, P., Schmidt, P., Shin, Y. 1992. Testing the null hypothesis of stationarity against the alternative of a unit root. Journal of Econometrics, 54(1992): 159-178. https://doi.org/10.1016/0304-4076(92)90104-Y

Nejat, P., Fatemeh Jomehzadeh, Mohammad Mahdi Taheri, Mohammad Gohari and Muhd Zaimi Abd. Majid, 2015. A global review of energy consumption, $\mathrm{CO} 2$ emissions and policy in the residential sector (with an overview of the top ten $\mathrm{CO} 2$ emitting countries). Renewable and Sustainable Energy Reviews, 43: 843-862. https://doi.org/10.1016/j.rser.2014.11.066

Ozturk, I. and Ali Acaravci, 2010. CO2 emissions, energy consumption and economic growth in Turkey. Renewable and Sustainable Energy Reviews, 14(9): 3220-3225. https://doi.org/10.1016/j.rser.2010.07.005 


\section{ENTREPRENEURSHIP AND SUSTAINABILITY ISSUES}

ISSN 2345-0282 (online) http://jssidoi.org/jesi/ 2019 Volume 7 Number 1 (September) http://doi.org/10.9770/jesi.2019.7.1(36)

Pao, H.T., Tsai, C.M. 2010. Multivariate Granger causality between CO2 emissions, energy consumption, FDI (foreign direct investment) and GDP (gross domestic product): Evidence from a panel of BRIC (Brazil, Russian Federation, India, and China) countries Energy, 36 (1): 685-693. https://doi.org/10.1016/j.energy.2010.09.041

Perron P. 1989. The great crash, the oil price shock, and the unit root hypothesis. Econometrica, 57(6): 1361-1401.

Pesaran, M.H., Shin, Y. 1999. An autoregressive distributed lag modeling approach to cointegration analysis. In: Strom S. (ed.): Econometrics and Economic Theory in the 20th Century. Cambridge University Press, Cambridge: $371-413$

Pesaran, M.H., Shin, Y., Smith, R. 2001. Bounds testing approaches to the analysis of level relationships. Journal of Applied Econometrics, 16: 289-326. https://doi.org/10.1002/jae.616

Phillips, P. C., \& Perron, P. 1988. Testing for a unit root in time series regression. Biometrika, 75(2): 335-346 https://doi.org/10.1093/biomet/75.2.335

Sekrafi, H. \& Sghaier, A. 2018. The effect of corruption on carbon dioxide emissions and energy consumption in Tunisia. PSU Research Review, 2(1): .81-95, https://doi.org/10.1108/PRR-11-2016-0008

Sekrafi, H. \& A. Sghaier, 2018. Examining the relationship between corruption, economic growth, environmental degradation, and energy Consumption: a panel analysis in MENA Region. Journal of the Knowledge Economy, 9(3): 963-979. https://doi.org/10.1007/s13132-016$\underline{0384-6}$

Shahbaz, M., Dube, S., Ozturk, I., Jalil, A. 2015. Testing the Environmental Kuznets Curve Hypothesis in Portugal. International Journal of Energy Economics and Policy, 5(2): 475-481.

Shahbaz, M., Ozturk, I., Ali, A. 2013. Revisiting the Environmental Kuznets Curve in a global economy. Renewable and Sustainable Energy Reviews, 25: 494-502. https://doi.org/10.1016/j.rser.2013.05.021

Shahzad, S.J., Kumar, R., Zakaria, M. \& Maryam Hurr, 2017. Carbon emission, energy consumption, trade openness and financial development in Pakistan: A revisit. Reviews, 70: 185-192. https://doi.org/10.1016/j.rser.2016.11.042

Shin Y, Yu B, Greenwood-Nimmo M. 2014. Modelling asymmetric cointegration and dynamic multiplier in an ARDL framework. In Festschrift in honor of Peter Schmidt: Econometric Methods and Applications, Eds. Horrace WC, Sickles RC. Springer Science and Business Media, New York, 281-314; ISBN: 1489980075.

World Bank (2019): World Development Indicators. Available at http://databank.worldbank.org/data/views/reports/tableview.aspx?isshared=true

Wang, Z., Danish, Bin Zhang and Bo Wang 2018. The moderating role of corruption between economic growth and CO2 emissions: Evidence from BRICS economies. Energy, 148: 506-513 https://doi.org/10.1016/j.energy.2018.01.167

Yang, X., Lou, F., Sun, M., Wang, M., Wang, Y. 2017. Study of the relationship between greenhouse gas emissions and the economic growth of Russia based on the environmental Kuznets curve. Applied Energy, 193: 162-173. https://doi.org/10.1016/j.apenergy.2017.02.034

Zhang, Y. Yan-Lin Jin, Julien Chevallier and Bo Shen, 2016. The effect of corruption on carbon dioxide emissions in APEC countries: A panel quantile regression analysis. Technological Forecasting and Social Change, 112; $220-227$. https://doi.org/10.1016/j.techfore.2016.05.027 
Dmitry BURAKOV is PhD in Economics, associate professor, department "Banks, Monetary Circulation and Credit", Moscow State Institute of International Relations (MGIMO-University), Moscow, Russia. Research interests: financial economics, envirionmental economics, energy economics.

ORCID ID: https://orcid.org/0000-0003-3019-5200

Alexander BASS is PhD in Economics, associate professor, department of financial markets and banks, Financial University under the Government of the Russian Federation, Moscow, Russia. Research interests: financial economics, energy economics.

ORCID ID: https://orcid.org/0000-0003-2471-9469

Author ID: 57195960963 